\title{
Developing Leadership Through "Serviceship": Leveraging the Intersection Between Service-Learning and Professional Internship
}

\author{
Lindsay J. Hastings, Ph.D. \\ Clifton Professor in Mentoring Research \\ Director, Nebraska Human Resources Institute \\ University of Nebraska \\ Milan Wall \\ Co-Director \\ Heartland Center for Leadership Development \\ Lincoln, Nebraska \\ Kurt Mantonya \\ Senior Associate \\ Heartland Center for Leadership Development \\ Lincoln, Nebraska
}

\begin{abstract}
Considering the role of higher education in preparing the next generation of leaders for social change, leadership education is challenged to consider how best to prepare young adults for socially responsible leadership. Service-learning and professional internships, separately, have been identified as vehicles for preparing young adults for leadership roles. The purpose of this Application Brief is to describe a hybrid of service-learning and professional internships, called "Serviceship," which employs undergraduate students as interns for a community rather than a company. Now in its fifth year at a Midwestern, four-year land-grant institution, the "Serviceship" program has placed 21 interns in 11 rural communities. Utilizing an asset-based community development framework, undergraduate students are matched with rural communities whose local leaders have self-identified a community development project.
\end{abstract}

\section{Issue Statement}

Higher education plays a pivotal role in shaping leadership quality (Astin \& Astin, 2000) and is increasingly called to purposefully develop socially responsible leaders (Dugan \& Komives, 2007). The Council for the Advancement of Standards in Higher Education (CAS), the Association of American Colleges \& Universities (AAC\&U), the National Association of Student Personnel Administrators (NASPA), the American College Personnel Association (ACPA), disciplinary accreditor members of the Council for Higher Education Accreditation (CHEA), and the Degree Qualification Profile (DQP) all offer student learning outcomes in higher education related to the development of leadership and social responsibility (see Table 1-Adelman, Ewell, Gaston, \& Schneider, 2011; AAC\&U \& NLC, 2007; CAS, 2009; Dreschsler Sharp, Komives, \& Fincher, 2011; Keeling, 2004). 
Table 1

Higher Education Learning Outcomes Related to Leadership and Social Responsibility

\begin{tabular}{|c|c|c|c|c|}
\hline CAS & AAC\&U & $\begin{array}{c}\text { NASPA and } \\
\text { ACPA }\end{array}$ & $\begin{array}{c}\text { Disciplinary } \\
\text { Accreditor } \\
\text { Members of } \\
\text { CHEA }\end{array}$ & DQP \\
\hline \multirow{6}{*}{$\begin{array}{l}\text { Intrapersonal } \\
\text { development } \\
\text { Interpersonal } \\
\text { competence } \\
\text { Humanitarianism } \\
\text { \& civic } \\
\text { engagement }\end{array}$} & \multirow{6}{*}{$\begin{array}{l}\text { Personal and } \\
\text { social } \\
\text { responsibility }\end{array}$} & \multirow{2}{*}{$\begin{array}{l}\text { Interpersonal and } \\
\text { intrapersonal } \\
\text { competence }\end{array}$} & \multirow{2}{*}{$\begin{array}{l}\text { Intrapersonal } \\
\text { attributes and } \\
\text { competencies }\end{array}$} & \multirow[t]{6}{*}{ Civic learning } \\
\hline & & & & \\
\hline & & Humanitarianism & \multirow{2}{*}{$\begin{array}{l}\text { Interpersonal } \\
\text { relations with } \\
\text { diverse others }\end{array}$} & \\
\hline & & $\begin{array}{l}\text { Civic } \\
\text { engagement }\end{array}$ & & \\
\hline & & & Ethics & \\
\hline & & & $\begin{array}{l}\text { Management } \\
\text { and } \\
\text { collaborative } \\
\text { leadership }\end{array}$ & \\
\hline
\end{tabular}

Considering the role of higher education in preparing the next generation of leaders for social change, leadership education is challenged to consider how best to prepare young adults for socially responsible leadership. Service-learning and professional internships, separately, have been identified as vehicles for preparing young adults for leadership and civic responsibility. The AAC\&U identified service-learning and internship participation as two of 10 high-impact practices for fostering engagement, persistence, and learning among college students (AAC\&U \& NLC, 2007). Additionally, several recent empirical studies have documented a positive relationship between service participation, internships, and socially responsible leadership (Dugan \& Komives, 2010; Kilgo, Sheets, \& Pascarella, 2015; Thompson, 2006). The purpose of this Application Brief is to describe and examine a hybrid of service-learning and professional internships, called "Serviceship." Now in its fifth year of operation at a Midwestern, four-year land-grant institution, the "Serviceship" program employs undergraduate students as interns for a community rather than a company. Designed using an asset-based community development approach, students engage in service-learning pedagogy in a professional internship alongside rural community leaders who have a self-identified community development project.

\section{Review of Relevant Literature}

Given the consensus of learning outcomes in higher education that relate to the development of leadership and social responsibility, collegiate leadership education serves as one of the most important preparatory training devices for socially responsible leadership. Separately, service-learning and professional internships have been identified as vehicles for preparing young adults for leadership roles. Thompson (2006), for example, examined the relationship between internships, volunteer service, and leadership aptitudes and beliefs among 
$(\mathrm{N}=453)$ upperclassmen students at a private liberal arts institution. MANOVA results revealed a positive association between internships and leadership aptitudes and beliefs as well as between volunteer service and leadership aptitudes and beliefs. As previously mentioned, the AAC\&U identified service-learning and internship participation as two of 10 high-impact practices for fostering college student engagement, persistence, and learning. Dugan and Komives (2010) examined the influence of higher education experiences on college students' capacity for socially responsible leadership. Hierarchical regression analyses on data from $(\mathrm{N}=$ 14,252) college seniors nationwide revealed community service involvement as a positive influence on the development of socially responsible leadership. More recently, Kilgo et al.'s (2015) OLS regression analyses revealed a positive and predictive relationship between internship experiences and socially responsible leadership using data from the Wabash National Study of Liberal Arts Education $(n=1,838)$.

To date, however, little research and practical literature have been dedicated to exploring the hybrid between service-learning and professional internships and its potential for unique positive impact on both students and community partners. In fact, some service-learning literature has been specifically dedicated toward separating service-learning and internships (Bringle \& Steinberg, 2010; Furco, 1996), citing students as the primary beneficiary in an internship, while both students and communities should benefit reciprocally in a service-learning scenario (Furco, 1996). What would happen, however, if students were hired as interns for a community rather than a company, and the internship experience utilized service-learning pedagogy, dedicating equal focus to service and reflection? The service-learning literature is increasingly calling for community engagement that involves asset-based community development as opposed to traditional deficit-based service initiatives designed to fix a community's problems (Donaldson \& Daughtery, 2011; Hamerlinck, \& Plaut, 2014). The goal of asset-based community development is to build a community's own capacity by leveraging local assets, such as the skills and talents of individual community members (human capital), formal and informal networks among community members (social capital), and institutions like schools, churches, and community centers (built capital) (Flora \& Flora, 2004; Kretzmann \& McKnight, 1993; McKnight \& Block, 2010, 2012). Considering the goal of asset-based community development, utilizing college students purely to provide voluntary service to the community may fall short of the intended outcomes of asset-based community development. By hybridizing with a community-based professional internship, service-learning initiatives can create value-added partnerships with communities by recognizing and leveraging local assets, yet drawing appropriate expertise from undergraduate students and faculty.

\section{Description of the Application}

We conceptualize serviceship as a hybrid of the traditional professional internship with the pedagogy of service-learning. Utilizing an asset-based community development framework, undergraduate students serve as interns for a community rather than a company and are matched with rural communities whose local leaders have self-identified a community development project.

In its fifth year at a Midwestern, four-year land-grant institution, the Serviceship program has placed 21 students in 11 rural communities. The Serviceship program is a collaborative 
effort, bringing together university student affairs and civic engagement staff, university faculty and administrators, as well as a non-profit rural community leadership development organization. Undergraduate students are recruited during the academic semesters by faculty and staff, while communities are recruited year round by the rural community leadership organization.

Based upon the pool of selected students and community projects, students are matched in teams of two to communities that fit their knowledge base and interest. Each team and community project is also assigned a faculty mentor whose research and expertise match the demands of the unique community project. During the month of May, the undergraduate students engage in a two-week training course in community development, taught in partnership between the rural community leadership development organization and university faculty and staff. Students interface with content related to asset-based community development, namely community capitals (Flora \& Flora, 2004), appreciative inquiry (Hammond, 2013), and clues to rural community survival (Luther \& Wall, 2008). This two-week course includes two field trips to rural communities within a short distance to the university to conduct analyses in community asset identification and applying community leadership to address local challenges and opportunities.

Each student team is then sent to their respective communities for nine weeks to execute the locally identified project alongside community leaders. Throughout the duration of the Serviceship, students prepare biweekly reflections on their experiences and have two to three site visits from faculty mentors, staff from the rural community leadership development organization, and/or university faculty and staff involved in the Serviceship program. Upon return to campus, the undergraduate students present their locally identified project and final reflections to the Serviceship faculty and staff team.

Highlighted below are the objectives associated with the participating communities, students, and faculty:

Community objectives:

- Complete locally identified project based on community priorities

- Gain access to talent and expertise (students/faculty)

- Build synergy between communities and university

- Increase community capacity to address local challenges and opportunities Student objectives:

- Work in a team-based approach to answer a community's question

- Engage in meaningful work that increases professional capacity

- Build social capital and civic engagement

- Discover opportunities in rural life

Faculty objectives:

- Engage communities and apply expertise to local questions.

- Develop students via community-based professional experience

- Build statewide collaboration for future work

- Deliver on the Land Grant promise 
Since the inception of the Serviceship program in 2013, community projects have ranged from developing community marketing plans to facilitating historic preservation efforts to establishing alumni database tracking systems to developing youth entrepreneurship curriculum. Students are offered a stipend, which has been shared between the community and the university, and the community has been responsible for providing no-cost housing.

\section{Discussions of Outcomes}

As previously mentioned, since 2013 the Serviceship program has placed 21 students in 11 rural communities. In four of the 11 communities, students created community marketing and branding campaigns - three for the community at-large and one for the local community foundation. In two of the 11 communities, students facilitated historic preservation efforts. One intern team conducted historical research on Main Street buildings and created plaques for each building, telling the story of the community throughout history. In the second team, students took an inventory of historic homes to document their merit and need, then conducted rehabilitation projects of historic homes in need. Two of the remaining 11 communities engaged students to create alumni tracking systems and recruitment strategies to bring back local alumni. In two additional communities, students built a countywide secondary entrepreneurship curriculum, bringing together local entrepreneurs and business owners with high school students. In the remaining community, students developed a tourism promotion plan and research library for a local museum.

The Serviceship students not only executed their locally identified project, but also were heavily engaged in community leadership activity and voluntary service. Students were asked to attend local civic group meetings (e.g., Rotary, Kiwanis, etc.) as well as local leadership meetings through the Chamber of Commerce or economic development offices. Additionally, students were asked to participate in local volunteering opportunities. Students volunteered their time through county fairs, vacation bible school, and local festivals.

Qualitative program evaluation feedback was collected each year from both students and participating community leaders. Overall evaluative feedback from both community leaders, faculty, and students indicated satisfaction and perception of value from the Serviceship program. For example, one community leader articulated, "The [Institute's] Serviceship program was incredibly valuable to [our town]. We received high-capacity interns who championed community betterment and delivered professional products that still impact [our town] two years later." Another example of community leader feedback included:

[Our town and county] received exponential benefits by hosting [Institute] interns. Our interns' unique perspectives, knowledge and insights have taken many of our local alumni recruitment, business promotion and youth engagement programs to new levels all of which have had lasting impacts for the greater good of our county-wide community.

One community leader articulated the reciprocal benefit of the Serviceship program (commensurate with service-learning pedagogy; Furco, 1996): "I feel that I have learned just as 
much from their knowledge and their perspectives about our community and about rural [State], as they have about their experience here in our community."

In addition to community leaders, faculty also provided positive feedback as to the potential of this Serviceship experience. One faculty member on the administration team discussed the impact of the Serviceship students from his perspective: "These young people bring a new perspective. They help a community see themselves differently. Often times better and often times with a lot more hope, than perhaps they saw themselves previously." Another faculty member contextualized the Serviceship experience in terms of a difference-making opportunity: "I think probably the biggest thing that hit home for me was this whole idea of giving students an opportunity to make a difference. And through an internship where they are not a cog in the wheel, but rather they are an intern for a community and they are there for the purpose of developing community. They have the most unique opportunity to make a difference."

Relative to the impact of the Serviceship program on students, one example of student feedback included: "My experience enhanced my appreciation for integrity, empathy, selfconfidence, and social judgment skills." Another example of positive student feedback included: "Looking back on this summer as a whole, it was great! Every time I tell someone what I was able to be a part of this summer they are always blown away! I've grown so much from this experience and am ecstatic I was able to partake in it." Several students echoed the sentiment as articulated by one student: "We actually had the opportunity to improve the community." One student expanded: "One of the greatest things that I value about this internship is we're actually getting to do hands-on things. And like taking ownership of these own projects instead of running coffee or doing paperwork and office work."

Additionally, students indicated in their final oral reflections: 1) Building relationships is the key to progress, 2) learning to communicate, cooperate and address challenges is critical to community success, and 3) rural communities have a future. Several students indicated that their vision for relocation upon starting their career changed from an urban location perspective to a rural perspective as a direct result of their experiences. One student articulated this notion even in her everyday living philosophy: "After I leave [Community], I think the biggest takeaway I am going to have is the rural community way of business and way of working - that everyone has relationships and utilizing resources to make a community work."

In addition to qualitative program evaluation evidence, an economic value study was conducted to more fully understand the nature and size of the Serviceship program impact on participating communities (Bader, 2016). Utilizing market research methods to analyze survey responses of previous Serviceship students and community leaders, Bader (2016) estimated the economic value created by the Serviceship students' work and volunteer contributions. Results from her economic value analysis revealed that the average value of one community Serviceship project is estimated at $\$ 15,790$, and the average value of the Serviceship experience per student is estimated at $\$ 8,422$. These figures indicate a significant return on investment for both the university and the community, considering that the university's average investment per community is estimated at $\$ 2,740$ (student stipend, mileage, training course) and the community investment (for two students) is estimated at $\$ 2,400$ plus housing (Bader, 2016). One 
community member articulated the return on investment qualitatively: "I would 100\% recommend this internship program to any communities looking at doing a project. We wanted to get the interns' perspective on marketing and we've gotten that ten times over."

\section{Reflections of Practitioner}

The serviceship idea delivers an interdisciplinary partnership for asset-based community development by coupling progressive community leaders with innovative, entrepreneurial student teams to build workable solutions in concert with university faculty and specialists. The combination of discipline, community engagement, and leadership training/experience creates human capacity and opens the door for active recruitment of new graduates and young professionals into the fabric of rural communities. The serviceship idea, in part, answers Jenkins's (2012) call for leadership education to be more transcendental considering its unique position to prepare future leaders across multiple disciplines. Additionally, the serviceship idea encourages Rosch and Schwartz's (2009) "integration strategy" of leadership development in higher education that encourages both the development of individual leader skills as well as the ability to relate and connect with others with the intention of developing organizations and promoting transformational change (p. 179). Beyond the value to leadership education in higher education institutions, the interdisciplinary nature of the serviceship idea and its capability for intersecting students, faculty, and community leaders provides the opportunity to build social capital - trust, norms, and networks within a community that facilitate coordinated action (Putnam, 1993) — which Ricketts (2009) reported as a critical variable in successful community leadership.

Through the Serviceship program, our intention behind hybridizing service-learning with a professional internship has been to show students that no matter what profession they seekwhether they want to be a doctor, lawyer, business owner, non-profit director - their job is to build community. Considering the role of higher education in preparing the next generation of leaders for social change, leadership educators may be better equipped to prepare college students for socially responsible leadership by intersecting service-learning and professional internships. While service-learning and professional internships, separately, influence the development of socially responsible leadership among college students (Dugan \& Komives, 2010; Kilgo et al., 2015; Thompson, 2006), the field of leadership education may benefit from examining the added value of using service-learning pedagogy in employing students as professional interns for communities rather than companies.

\section{Recommendations}

While overall program evaluation feedback was generally positive, we did receive helpful feedback from students and community participants on process and operational improvements. Below are three general categories of recommendations that are worth sharing for those who wish to replicate the program.

Community Readiness. Considering the student interns only had nine weeks to execute their respective community development projects, we learned early that community applications needed to outline a well-defined project (thorough description of proposed activities, 
collaborative partners identified, articulated plan for integrating students within the community, etc.) in order to demonstrate readiness for student success. Due to the nebulous nature of most community development efforts, Serviceship students needed to be able to hit the ground running with a well-defined project, so they could easily co-construct a plan of attack alongside local community leaders. In addition to a thorough description of the project, we recognized that community applications needed to demonstrate readiness by supplying multiple letters of support from a variety of community leadership entities (e.g., Chamber of Commerce, economic development offices, local banks, etc.) to demonstrate wide community support and knowledge of the community development project. This demonstration of readiness partially reflects Watt and Ziegler's (2009) discussion of Hackman and Johnson's (2009) necessary conditions for collaborative public ventures, namely broad-based involvement and visible, committed, highlevel community leaders.

We also learned that community readiness needed to include several communication opportunities prior to student arrival. Thus, within the two-week training course, Serviceship students and community leaders are now given the opportunity to begin outlining a plan of work, and the students are paid mileage to visit their host community prior to the start of their official Serviceship experience.

Local Media Coverage. Student success has been largely incumbent upon their ability to network within the community, and we learned that students were able to connect with local community leaders better if the community members were aware of the interns' arrival and were aware of their community development project. Thus, we began strongly encouraging community leaders to facilitate local media coverage (print media, radio and television interviews, etc.) of the students' work.

Local Housing. To our surprise, Serviceship students indicated during feedback sessions that they preferred in-home stays with local community members as compared to apartment or dormitory housing. Two students offered reflections specific to the importance and value of living and working in the same community. One student indicated, "This experience wouldn't be the same if we weren't doing a homestay, because we are not only working here, but we're living here and interacting with people." Another student expanded upon this notion by saying, "The people I might meet at work are people who I see at church, at the farmer's market...And realizing that you're a part of their lives for the summer. It's just a little bit different than other internships because you are a part of the community." Students reflected that staying in a home with local community members allowed them to integrate better within the community and facilitated their local networking efforts more smoothly.

Research Recommendations. In addition to practical recommendations, future empirical research will be necessary in order to provide confirmatory evidence as to the value of intersecting service-learning and internships in developing socially responsible leadership. Comparing pre- and post-Socially Responsible Leadership Scale (SRLS) scores (or then-now SRLS scores to avoid horizon effect-Rosch \& Schwartz, 2009) for Serviceship students, for example, would provide such an evaluative test. Additionally, leadership scholars may benefit from examining public polling data prior to intern arrival and after project completion to gauge 
changes in public perception of belief in community leadership, hope in the community's future, and civic engagement.

\section{References}

Adelman, C., Ewell, P., Gaston, P., \& Schneider, C. G. (2011). The degree qualification profile. Indianapolis, IN: Lumina Foundation.

Association of American Colleges \& Universities (AAC\&U), \& National Leadership Council (NLC) (US). (2007). College learning for the new global century: A report from the National Leadership Council for Liberal Education \& America's Promise. Washington, DC: Association of American Colleges \& Universities.

Astin, A. W., \& Astin, H. S. (2000). Leadership reconsidered: Engaging higher education in social change (Report ED 444 437). Battle Creek, MI: Kellogg Foundation.

Bader, J. (2016). Economic value of RFI Serviceship Program. Lincoln, NE: Rural Futures Institute.

Bringle, R. G., \& Steinberg, K. (2010). Educating for informed community involvement. American Journal of Community Psychology, 46: 428 - 441.

Council for the Advancement of Standards in Higher Education. (2009). CAS learning and development outcomes. In L. A. Dean (Ed.), CAS professional standards for higher education $\left(7^{\text {th }}\right.$ ed.). Washington, DC: Author.

Donaldson, L. P., \& Daughtery, L. (2011). Introducing asset-based models of social justice into service learning: A social work approach. Journal of Community Practice, 19(1), 80 - 99.

Dreschsler Sharp, M., Komives, S. R., \& Fincher, J. (2011). Learning outcomes in academic disciplines: Identifying common ground. Journal of Student Affairs Research and Practice, 48(4), $481-504$.

Dugan, J. P., \& Komives, S. R. (2007). Developing leadership capacity in college students: Findings from a national study. A Report from the Multi-Institutional Study of Leadership. College Park, MD: National Clearinghouse for Leadership Programs.

Dugan, J. P., \& Komives, S. R. (2010). Influences on college students' capacities for socially responsible leadership. Journal of College Student Development, 51(5), 525 - 549.

Flora, C. B., \& Flora, J. L. (2004). Rural communities: Legacy and change (2 ${ }^{\text {nd }}$ Ed.). Boulder, CO: Westview Press.

Furco, A. (1996). Service-learning: A balanced approach to experiential education. In Corporation for National Service (Ed.), Expanding boundaries: Serving and learning (pp. 
2 -6). Columbia, MD: The Cooperative Education Association.

Hackman, M. Z., \& Johnson, C. E. (2009). Leadership: A communication perspective (5 ${ }^{\text {th }}$ ed.). Prospect Heights, IL: Waveland.

Hamerlinck, J., \& Plaut, J. (2014). Asset-based community engagement in higher education. Minneapolis, MN: Minnesota Campus Compact.

Hammond, S. A. (2013). The thin book of appreciative inquiry ( $3^{\text {rd }}$ ed.). Bend, OR: Thin Book Publishing Co.

Jenkins, D. M. (2012). Exploring signature pedagogies in undergraduate leadership education. Journal of Leadership Education, 11(1), 1 - 27.

Keeling, R. (Ed.). (2004). Learning reconsidered: A campus-wide focus on the student experience. Washington, DC: National Association of Student Personnel Association Administrators (NASPA) and American College Personnel Association (ACPA).

Kilgo, C. A., Sheets, J. K. E., \& Pascarella, E. T. (2015). The link between high impact practices and student learning: Some longitudinal evidence. Higher Education, 69, $509-$ 525 .

Kretzman, J. P., \& McKnight, J. L. (1993). Building communities from the inside out: A path toward finding and mobilizing a community's assets. Evanston, IL: Institute for Policy Research, Northwestern University.

Luther, V., \& Wall, M. (2008). Clues to rural community survival. Lincoln, NE: Heartland Center for Leadership Development.

McKnight, J., \& Block, P. (2010, 2012). The abundant community: Awakening the power of families and neighborhoods. San Francisco, CA: Berrett-Koehler Publishers, Inc.

Keeling, R. (Ed.). (2004). Learning reconsidered: A campus-wide focus on the student experience. Washington, DC: National Association of Student Personnel Association Administrators (NASPA) and American College Personnel Association (ACPA).

Putnam, R.D. (1993). Making democracy work: Civic traditions in modern Italy. Princeton, NJ: Princeton University Press.

Ricketts, K. G. (2009). Studying leadership within successful rural communities in a southeastern state: A qualitative analysis. Journal of Leadership Education, 7(3), 230 245 .

Rosch, D. M., \& Schwartz, L. M. (2009). Potential issues and pitfalls in outcomes assessment in leadership education. Journal of Leadership Education, 8(1), 177 - 194. 
Thompson, M. D. (2006). Student leadership process development: An assessment of contributing college resources. Journal of College Student Development, 47(3), 343 350 .

Wyatt, W. M., \& Ziegler, A. H. (2009). Empowering community members for civic leadership: The institute for community leadership. Journal of Leadership Education, 7(3), 28 - 49.

\section{Author Biographies}

Lindsay Hastings, Ph.D. is the Clifton Professor in Mentoring Research and Director of Nebraska Human Resources Institute (NHRI), a leadership mentoring organization at the University of Nebraska. Hastings teaches courses in leadership theory and interpersonal skills for leadership, and her research interests include generative leadership and social responsibility. Email at lhastings2@unl.edu.

Milan Wall is a founder and Co-Director of the Heartland Center for Leadership Development, an independent nonprofit organization developing local leadership for community vitality. He is the author of more than a dozen publications on leadership and community development and is a frequent speaker throughout the U.S. Email at mwall@heartlandcenter.info.

Kurt Mantonya, Senior Associate at the Heartland Center for Leadership Development, is an applied anthropologist with more than 15 years of community experience in the Central Plains and Southwest. He has degrees from Kansas State University and the University of Nebraska in sociology and anthropology. Email at kmantonya@ heartlandcenter.info. 